\title{
In vitro study of the dose effect of Saccharomyces cerevisiae on rumen digestion of a mixed diet
}

\author{
JP Jouany 1, B Lassalas 1, G Bertin 2 \\ IINRA, SRNH, Theix, 63122 St-Genès-Champanelle ; ${ }^{2} \mathrm{CSI}$, Direction $R$ and $D$, \\ 94, rue Edouard Vaillant, 92532 Levallois-Perret, France
}

Live yeasts, used as feed additives, have been suggested as a mean of stabilizing rumen microbial digestion in animals fed diets rich in starch (RJ Wallace and J Newbold, 1992, Probiotics. The scientific basis, Chapman and Hall, 317-353). Three doses of Saccharomyces cerevisiae $(1-1077)^{\star}$ (SC) were tested in Rusitec to study their effects on rumen digestive parameters. The four fermentors were first inoculated with mixed rumen digesta sampled from three sheep fed on grass hay $(700 \mathrm{~g} / \mathrm{d})$, barley $(400 \mathrm{~g} / \mathrm{d})$ and soybean meal (100 g/d). Each fermentor (1 I) was fed daily $10 \mathrm{~g}$ grass hay $+6 \mathrm{~g}$ barley $+2 \mathrm{~g}$ fishmeal $+1 \mathrm{~g}$ sucrose in a nylon bag $50 \mu \mathrm{m}$ in mesh size, which was changed every $48 \mathrm{~h}$. A Mc Dougall-type saliva with trace elements, urea (200 mg/d) and $\mathrm{Na}_{2} \mathrm{SO}_{4}(90.4 \mathrm{mg} / \mathrm{d})$, was infused continuously at the rate of $700 \mathrm{ml} / \mathrm{d}$. Nylon bags were vertically agitated at a rate of $40 \mathrm{~cm} / \mathrm{min}$. Yeast were given in dry form, once per day, when the fermentors were fed.

The addition of SC significantly improved the digestibility of OM and cell wall components whatever the dose ; the increase was greatest at the dose of $10^{5} \mathrm{CFU}$. VFA production only increased with the $10^{5} \mathrm{CFU}$; the composition of VFA mixture was not influenced by SC. As a consequence, fermented organic matter (FOM) calculated from DI Demeyer and CJ Van Nevel (1975, Digestion and Metabolism in the Ruminants, University of New England Publishing $\mathrm{Co}, 366-382)$ was highest with the $10^{5} \mathrm{CFU}$. Gas production and composition, $\mathrm{NH}_{3}-\mathrm{N}$ concentration and $\mathrm{pH}$ in fermentors were not altered by SC, nor the efficiency of microbial protein synthesis (EMPS). Administred at the concentration of $10^{5} \mathrm{CFU} / \mathrm{ml}, \mathrm{SC}$ had the highest effect on plant cell wall digestion and VFA production in Rusitec. Compared to results of in vivo studies, the response of microbial cellulolytic activities to $\mathrm{SC}$ in Rusitec was amplified. This suggests that Rusitec could not be suitable for probiotic studies.

(This work was supported by CSI LevalloisPerret, France. The authors thank M Fabre and $P$ Journaix for their skilled technical assistance).

\begin{tabular}{|c|c|c|c|c|}
\hline & \multirow[t]{2}{*}{ Control } & \multicolumn{3}{|c|}{ Yeast supply (CFU/ml) } \\
\hline & & $10^{4}$ & $10^{5}$ & $10^{6}$ \\
\hline NDF digestibility (\%) & $36.4^{a}$ & $42.8^{\mathrm{b}}$ & $47.5^{c}$ & $46.1 \mathrm{c}$ \\
\hline VFA production (mMol/d) & $63.6^{a}$ & $58.4 a$ & $76.8^{b}$ & $69.9 \mathrm{ab}$ \\
\hline Acetate/propionate & $2.4^{a}$ & $2.5^{\mathrm{a}}$ & $2.5^{\mathrm{a}}$ & $2.3^{a}$ \\
\hline FOM $(g / d)$ & $5.6^{a}$ & $5.2^{\mathrm{a}}$ & $6.8^{\mathrm{b}}$ & $6.2^{\mathrm{b}}$ \\
\hline Gas production (l/d) & $1.9 \mathrm{a}$ & $1.7^{\mathrm{a}}$ & $2.0 \mathrm{a}$ & $2.0^{\mathrm{a}}$ \\
\hline $\mathrm{CO}_{2} / \mathrm{CH}_{4}$ & $4.5^{\mathrm{a}}$ & $3.9^{a}$ & $3.8 \mathrm{a}$ & $4.1^{\mathrm{a}}$ \\
\hline EMPS (g N/kg FOM) & $22.9^{a}$ & $22.7^{\mathrm{a}}$ & $19.3^{a}$ & $23.3^{a}$ \\
\hline
\end{tabular}

* registered at Institut Pasteur, Paris. 